\title{
特別講演 $(1)$
}

\section{未分化細胞からの臓器形成}

東京大学大学院総合文化研究科生命系 浅島 誠

私達ヒトを含めて動物の体は様々な臓器から構成されている。それらの臓器が発 生過程でどのような遺伝子のカスケードのもとに形成されてくるのか。またそれら の臓器の集合体としての個体はどのようなメカニズムで統一された形づくりをする のか. このような問題をツメガエルやイモリ卵を使って試験管で証明してきた。そ して, 試験管で行った蔵器形成や形づくりが正常肧の発生プログラムとどこまで同 じであるかについても検証した結果，それらはほとんど同じであることがわかって きた。

両生類の胞胚のアニマルキャップ(未分化細胞塊)を用いて，試験管内で現在まで に 15 種類の様々な臓器形成が可能となっている. それらは未分化細胞にアクチビン を処理すると濃度依存的に様々な器官や組織を分化誘導する。低濃度では腹側の血 球や体腔内上皮，中濃度では筋肉，高濃度では脊索を分化誘導する。更に高濃度に すると拍動する心臓や小腸，肝臓といった内肧葉性器官も分化誘導する。このよう な時，試験管内でつくられた心茞は単に拍動するという生理的機能のみならず，電 顕で見ると介在板もはっきりと見られるし，心筋に特異的遺伝子の発現も確認され た. また試験管内でのアクチビン $(10 \mathrm{ng} / \mathrm{ml})$ とレチノイン酸 $(10-4 \mathrm{M})$ との混合によ り，原腎管(腎臓)を 100\%分化誘導することができる.またアクチビンとレチノイン 酸の時間差処理によってインスリンやグルカゴンを分泌する膵臓形成をすることが できる。つまり内分泌器官を未分化細胞からつくることもできたのである。ところ で腎管形成について分子生物学的に解析すると, 試験管内では正常発生と同じよう に腎管に次々と規則正しくXlim, XPax8つづいてXCIRP，XWTI， $\mathrm{Na}+, \mathrm{K}+-$ ATPase, XCaax-1 などの遺伝子が発現してくる.またこの系をつかって新規の腎形 成に関与する遺伝子もクローニングされ，解析されている，次に試験管内でつくっ た原腎管を腎臓予定域を除去した胚に移植した。コントロールとしてはアニマル キャップを移植し，実験胚ではアニマルキャップにアクチビンとレチノイン酸処理 片を移植した。その結果，コントロール肧では 10 日以内に水腫をおこして全滅する が, 処理した移植肧では 1 ケ月以上生存が可能となった. 試験管内で未分化細胞から 腎管をつくって生体に移植してそれが機能することも明らかになった。また形づく りについては頭部構造や胴尾部構造も試験管内で行うことが可能となっている.そ 
こで，それらの神経形成や胴尾部形成に関与している遺伝子とそこに働く他の因子 との相互関係などもしだいに明らかになってきている。このようにしてみると，現 在, 動物の初期発生において様々な臓器東京大学大学院総合文化研究科生命系形成 が in vitro 系(試験管内) で可能になっており，しかもそこに係わる遺伝子群が次第 に明らかにされてきている。また目や耳といって感覚器官の形成も in vitro 系(試験 管内) で可能になってきている.それでは現状ではどこまで試験管内で蔵器形成が可 能であるのか, 今後, 上記のようなアニマルキャップなどの未分化細胞や ES 細胞か らの臓器形成, また成体にある stem cells (幹細胞) からの臓器形成についての検討と 今後のこの分野での展望などについても述べてみたい. 